\title{
Groundwater Risk Assessment in the Context of an Underground Coal Mine Closure and an Economic Evaluation of Proposed Treatments: A Case Study
}

\author{
Gregorio Fidalgo Valverde ${ }^{1, *(\mathbb{D}}$, Adam Duda ${ }^{2}$, Francisco Javier Iglesias Rodríguez ${ }^{1} \mathbb{(}$, Aleksander Frejowski ${ }^{2}(\mathbb{D}$ \\ and Ivan Todorov ${ }^{3}$ \\ 1 School of Mining, Energy and Materials Engineering, University of Oviedo, Independencia 13, \\ 33004 Oviedo, Spain; fjiglesias@uniovi.es \\ 2 Department of Risk Assessment and Industrial Safety, Central Mining Institute, Plac Gwarków 1, \\ 40-166 Katowice, Poland; aduda@gig.eu (A.D.); afrejowski@gig.eu (A.F.) \\ 3 Department of Drilling, Oil and Gas Production \& Transport, University of Mining and Geology "Saint Ivan \\ Rilsky", 1700 Sofia, Bulgaria; ibt@mgu.bg \\ * Correspondence: gfidalgo@uniovi.es; Tel.: +34-985-104-284
}

check for

updates

Citation: Fidalgo Valverde, G.; Duda, A.; Iglesias Rodríguez, F.J.; Frejowski, A.; Todorov, I. Groundwater Risk Assessment in the Context of an Underground Coal Mine Closure and an Economic Evaluation of Proposed Treatments: A Case Study. Energies 2021, 14, 1671. https://doi.org/ $10.3390 /$ en14061671

Academic Editor: Ben McLellan

Received: 22 January 2021

Accepted: 12 March 2021

Published: 17 March 2021

Publisher's Note: MDPI stays neutral with regard to jurisdictional claims in published maps and institutional affiliations.

Copyright: (c) 2021 by the authors. Licensee MDPI, Basel, Switzerland. This article is an open access article distributed under the terms and conditions of the Creative Commons Attribution (CC BY) license (https:/ / creativecommons.org/licenses/by/ $4.0 /)$.

\begin{abstract}
Mining companies are responsible for the impacts that result from their mining activities even after the mining period has ended. At the same time, at the European and international levels, there is a lack of a detailed operational methodology comprising environmental risks during and after closure of underground coal mines. The environmental risk aspects that need to be considered when planning the closure of an underground coal mine and post closure in the broader environmental context are the following: modification of water flow scheme, surface instability, mine gas emission on the surface, and water and soil pollution. In this study, we focus on assessing groundwater risk in the context of an underground coal mine closure and evaluating the selected risk mitigation strategies in terms of performance and cost. The results from this study could be used for developing a final closure groundwater assessment plan by selecting the most feasible treatment alternatives for different environmental impacts, together with the transitional monitoring that could guarantee a hazard level in compliance with land reuse and the use of natural resources. Finally, the cost-efficient monitoring and treatment programs are used to estimate the financial provisions needed to mitigate groundwater risks during underground coal mine closure contexts.
\end{abstract}

Keywords: underground coal mine; groundwater risk assessment; mine closure; risk mitigation; economic evaluation; financial provision

\section{Introduction}

Mining companies are responsible for the impacts that result from their mining activities even after the mining period has ended. At the same time, at the European and international levels, there is a lack of a detailed operational methodology comprising environmental risks during and after closure of underground coal mines [1]. Up to this moment, several tools have been used to manage environmental risks in the context of mine closures, although they have mainly focused on mine reclamation or in very specific aspects of the closing process but without developing a detailed operational methodology. These include the following: the "Mining Risk Prevention Plan" in France, that evaluates the risks that are linked to pollution [2]; guidelines related to planning and implementing strategies for mine closure in Finland but within a global project of environmental techniques for extractive industries [3]; an impact assessment methodology for water management using risk assessment principles [4]; a strategic framework in order to develop mine closure plans although they are not detailed enough [5]; and finally, guidelines for mine closure in the United States and in Canada, with a mine reclamation approach [6]. 
To address this problem, one of the research objectives for coal within the Research Fund for Coal and Steel (RFCS) Program [7] is efficient protection of the environment and improved use of coal as a clean energy source. Within this objective, research projects should seek to minimize the impact of mining operations and the use of coal in the community on the atmosphere, water, and the surface within the framework of an integrated management strategy concerning pollution. As the community coal industry is undergoing constant restructuring, studies have been geared towards minimizing the environmental impact of underground mines destined for closure.

With this background, the RFCS MERIDA Project [8] was developed to design and provide technical guidance for implementing the necessary investigations that should be undertaken to build up an adequate mine closure plan. The aim was to minimize the environmental risks during mine closure and the post-closure periods following the general principle that the mine companies must take responsibility and minimize all risks that can be foreseen. In practical terms, the MERIDA Project has provided a planning tool for the design of a logical, stepwise approach to mine closure that can be progressively refined during the post-closure period, and therefore can address all relevant environmental risks.

The environmental risk aspects that should be considered when planning an underground coal mine closure and post closure in the broader environmental context are the following: modification of water flow scheme (e.g., flooding events, discharge scheme modification, and wet zones appearance), surface instability (subsidence, sinkholes, collapses, etc.) [9], mine gas emission on the surface (e.g., methane explosions, intoxication, and asphyxia) [10], and water and soil pollution [2].

In this paper, we present the RFCS MERIDA Project results concerning groundwater risk assessment, starting with the risk identification of areas exposed to groundwater risk. Mosquitera and Pumarabule underground coal mines, a property of the Spanish public company Hulleras del Norte, S.A. (HUNOSA) are used as a case study. The methodology employed was presented by Krzemień et al. [11].

After identifying the risks, the next step was to undertake a baseline qualitative assessment of the previously identified potential hazardous events and relevant impacts using a matrix for prioritization of risk. Then, the risks identified as being potentially significant or with an uncertain significance were subjected to detailed risk assessment using an appropriate method depending on the nature of the specific risk [12].

The determination of treatment alternatives for groundwater includes (1) strategies to prevent or minimize the risk and its impacts; (2) procedures and measures to manage the risk or effects with minimal short-term maintenance requirements; and (3) practices and actions that can manage the risk or impact of transitional-term maintenance and management.

Finally, the alternative risk mitigation strategies' performance was evaluated in terms of performance (reducing the risk to acceptable levels) and cost. The final closure assessment plans were elaborated by selecting the most feasible treatment alternatives for the different environmental impacts and the transitional monitoring that could guarantee a hazard level in compliance with the land use plan [13], the land reuse, or the use of natural resources.

\section{Materials and Methods}

\subsection{Pumarabule and Mosquitera Mines}

The Pumarabule mine or Pozo Pumarabule was started with the excavation of the first pit, Pumarabule 1, in 1916, by the Mining Engineer Joaquín Velasco, and operations began in 1917. In 1957, the second pit, Pumarabule 2, was excavated, reaching $578 \mathrm{~m}$ deep, with a diameter of $5.65 \mathrm{~m}$ and 13 levels. In 1969, the Pumarabule mine was integrated into Hulleras del Norte S.A. (HUNOSA, Asturias, Spain).

The underground exploitation of Pumarabule 1 and 2 is $578 \mathrm{~m}$ deep, developed over 14 floors or levels, and between 285.75 m.a.s.l. (meters above sea level) and -292.74 m.a.s.1. 
Topographically, both pits' head frames are located at a higher level than the rest of the underground workings in the area, except for the Saús mine.

The Mosquitera mine started with its excavation in 1946 (Pozo Mosquitera 1). In December 1989, there was a fire in the 7th level due to a burning transporting belt. The temperature reached $2000{ }^{\circ} \mathrm{C}$ and afterwards the fire spread to the coal seam. Four miners died and several miners were injured. The mine was closed, and from that moment, the exploitation continued through the Pumarabule mine, $700 \mathrm{~m}$ away from Pozo Mosquitera 1. The Pozo Mosquitera 2 was excavated in 1926.

Underground mining in Pozo Mosquitera 1 has a maximum depth of about $566 \mathrm{~m}$, developed in 8 floors with 11 levels between 269.36 and -296.73 m.a.s.l. Mosquitera 2 has five floors with seven levels and a maximum depth of $477.5 \mathrm{~m}$ ( -204.50 m.a.s.l.).

Another area is the Rosellón mine, which consists of 4 floors or levels of exploitation and has a maximum depth of $167 \mathrm{~m}$ (119.58 m.a.s.l). Its head frame is located around $500 \mathrm{~m}$ N.E. from Mosquitera 1, and its 4th floor is communicated with Mosquitera 1st floor.

Finally, the Saús mine has three floors or levels with a maximum depth of $123 \mathrm{~m}$; access to these floors or levels was performed with inclined galleries.

Figure 1 presents a schematic representation of the mines and the existing connections between them.

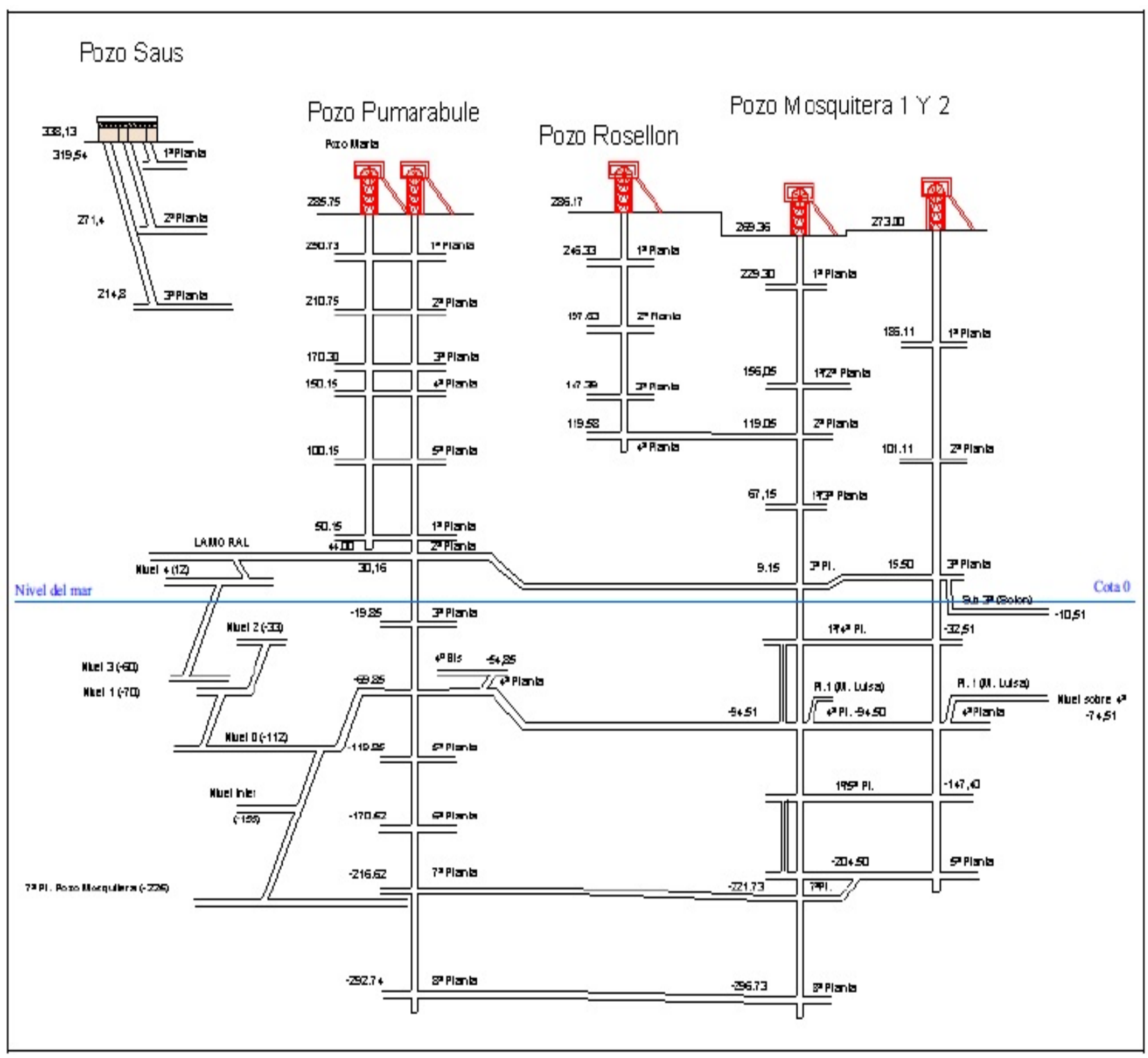

Figure 1. Connections between the mines (courtesy of Hulleras del Norte, S.A. (HUNOSA)). 
Figure 2 presents the geological section map of the two mines, as well as the surrounding environment such as the Candín river, the Candín mine, and the main fault of the area.

On 3 July 2015, the water reached 229.14 m.a.s.l. and the distance of the water level from the pitheads was $40.57 \mathrm{~m}$. From 9 November 2015, HUNOSA was authorized by the mining authority to increase the flooding level $5 \mathrm{~m}$, with a monthly increase of $1 \mathrm{~m}$. The flooding level should reach 235 m.a.s.l.

Five pumps were installed in the shafts ( 3 in Mosquitera and 2 in Pumarabule) to maintain the security level, i.e., in Mosquitera, three $37 \mathrm{~kW}$ pumps with a nominal flow of $225 \mathrm{~m}^{3} / \mathrm{h}$ each, and in Pumarabule, two $55 \mathrm{~kW}$ pumps with a nominal flow of $240 \mathrm{~m}^{3} / \mathrm{h}$ each. The Pumarabule mine is used as an auxiliary pumping facility for Mosquitera, so in Pumarabule, there is pumping when Mosquitera pumps cannot maintain the flooding level.
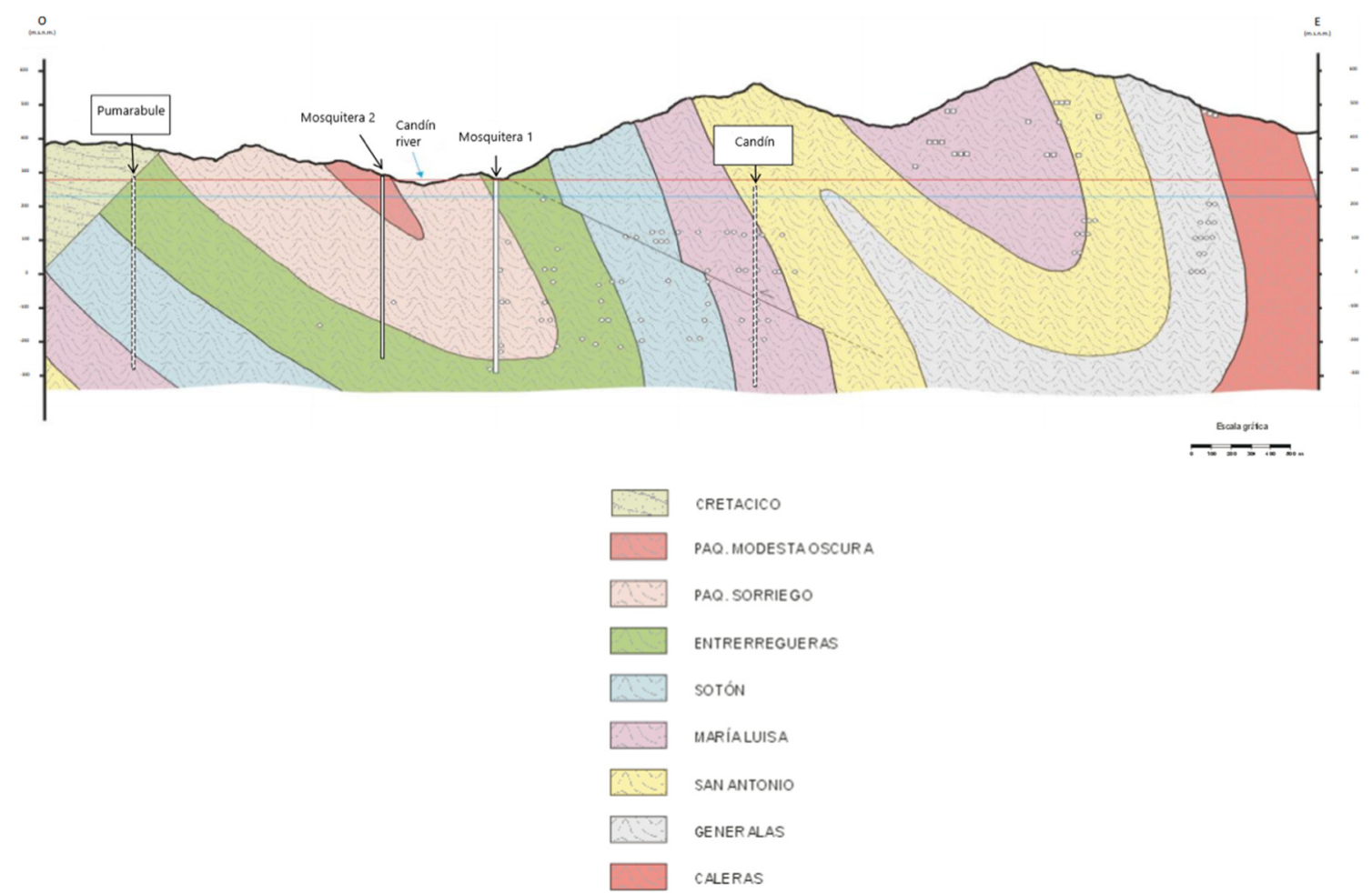

Figure 2. Geological section map of the two mines.

\subsection{Risk Management Process}

According to ISO 31000:2018 [14], risk management is the process whereby risk assessments are undertaken, and remedial actions are identified and implemented with follow-up.

After defining the necessary parameters for managing risk and setting the criteria for the rest of the process, risk assessment provides the structured approach that identifies how objectives may be affected and analyzes the risk in terms of consequences and probabilities before deciding whether further treatment is required.

Risk assessment is the overall process of risk identification, risk analysis, and risk evaluation. It should be conducted systematically, iteratively, and collaboratively, drawing on the knowledge and views of stakeholders. It should use the best available information, supplemented by a further enquiry as necessary, and take place within an overall framework of risk management, where any risks are treated, communicated, and monitored. 


\subsubsection{Establishing the Context: Risk Criteria}

Establishing the context is to customize the risk management process by establishing the risk criteria to be used for an adequate risk assessment and an appropriate risk treatment.

Risk criteria must be defined for every environmental risk factor to set the benchmark against which the risk assessment is undertaken or, in other words, the acceptable thresholds. These criteria must be based on regulatory requirements when applicable and should include stakeholders' concerns, considering both risk criteria for human beings and the environment.

The Whitehorse Mining Initiative [15] proposed the following scope: "To ensure that comprehensive reclamation plans that return all mine sites to viable, and, wherever practicable, self-sustaining, ecosystems are developed, and are adequately financed, implemented and monitored in all jurisdictions."

Within Europe, the control and monitoring of inland surface waters are subject to the following two European regulations: Directive 2006/44/E.C. on the quality of freshwaters needing protection or improvement to support fish life [16], and Directive 2000/60/E.C. that establishes a framework for Community action in the field of water policy [17].

Directive 2006/44/E.C. [16] sets the main parameters required by the regulations to be monitored in the rivers. Still, only the $\mathrm{pH}$ and the suspended solids among the variables analyzed by HUNOSA are specified for salmonid/trout waters. Artificial $\mathrm{pH}$ variations concerning the unaffected values shall not exceed \pm 0.5 of a $\mathrm{pH}$ unit within limits falling between 6.0 and 9.0 provided that these variations do not increase the harmfulness of other substances present in the water. In addition, suspended solids should be equal to or lower than $25 \mathrm{mg} / \mathrm{L}$.

The European national-level legislation should be addressed to find limits for the remaining parameters. While there are no references for them in Spain, Poland established the following threshold limit values for water contaminants from industry, including water from coal mine drainage [18]:

- $\quad$ The $\mathrm{pH}$ should be situated between 6.3 and 8.6;

- $\quad$ Suspended solids should be equal or lower than $32.7 \mathrm{mg} / \mathrm{L}$;

- Conductivity at $20^{\circ} \mathrm{C}$ should be lower than $2814 \mu \mathrm{S} / \mathrm{cm}$;

- Total iron should be lower than $10 \mathrm{mg} / \mathrm{L}$;

- Sulphates should be lower than $500 \mathrm{mg} / \mathrm{L}$.

\subsubsection{Risk Identification}

Risk identification aims to generate a comprehensive list of risks based on those events or effects that might create, enhance, prevent, degrade, accelerate, or delay the achievement of objectives that were established in the context. In health and safety terms, these events are hazards; in environmental terms, they are impacts.

A risk identification method improves the accuracy and completeness of identified underlying hazards and impacts that may produce these events.

Within the potential techniques that are strongly applicable for risk identification according to IEC/ISO 31010 [19], the following ones can be cited: brainstorming; structured or semistructured interviews; Delphi; checklists; primary hazard analysis; hazard and operability studies (HAZOP); hazard analysis and critical control points (HACCP); environmental risk assessment; structure "What if?" (SWIFT); scenario analysis; failure mode effect analysis (FMEA); cause-and-effect analysis; human reliability analysis; reliability centered maintenance; and consequence/probability matrix.

A cause-and-effect analysis was selected to identify the risks that may arise from these events. It is a structured method used to identify possible causes of an undesirable event or problem. The potential contributory factors were organized into broad categories so that all possible hypotheses could be considered. The information was collected in tree diagrams, providing a structured pictorial display of a list of causes of a specific effect. 


\subsubsection{Risk Analysis}

The risk analysis is about developing an understanding of the risk. It provides input for a risk assessment and decisions about whether risks need to be treated and the most appropriate treatment strategies and methods [19].

It consists of determining the consequences and their probabilities for identified risk events, considering the presence (or not) and the effectiveness of any existing controls. Then, the consequences and their probabilities are combined to determine a level of risk.

Methods used for analyzing risks can be qualitative, semiquantitative, or quantitative. The degree of detail required depends on the particular application, the availability of reliable data, and an organization's decision-making needs. In this case, risk evaluation was developed using a consequence/probability matrix or "risk matrix" where a subjective assessment is made on the two dimensions of risk to give a "risk score" that provides overall priority, but not accurate risk acceptability guidance.

Figure 3a presents the scale of consequences established according to the economic impact of losses as defined by mining insurance companies. Figure $3 \mathrm{~b}$ shows the probability scale or likelihood rating needed to span the range relevant for this study, remembering that the lowest probability must be acceptable for the highest defined consequence. Otherwise, all activities with the highest consequence are defined as intolerable.

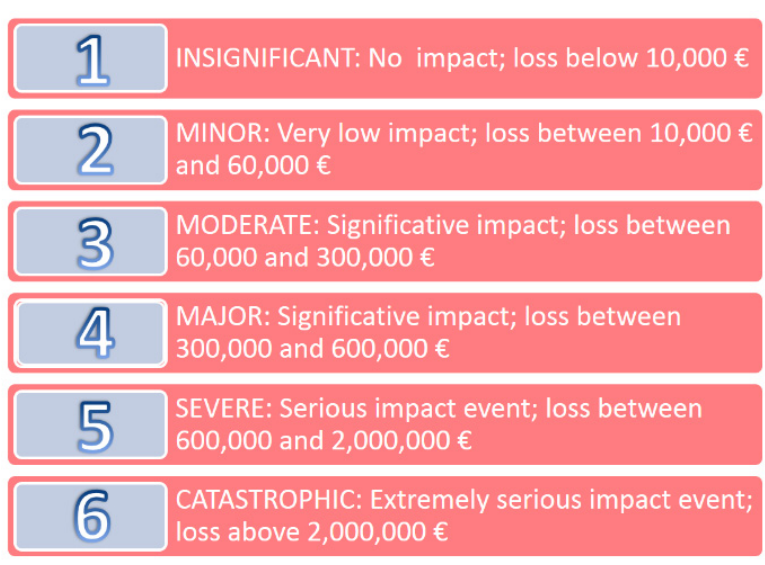

(a)

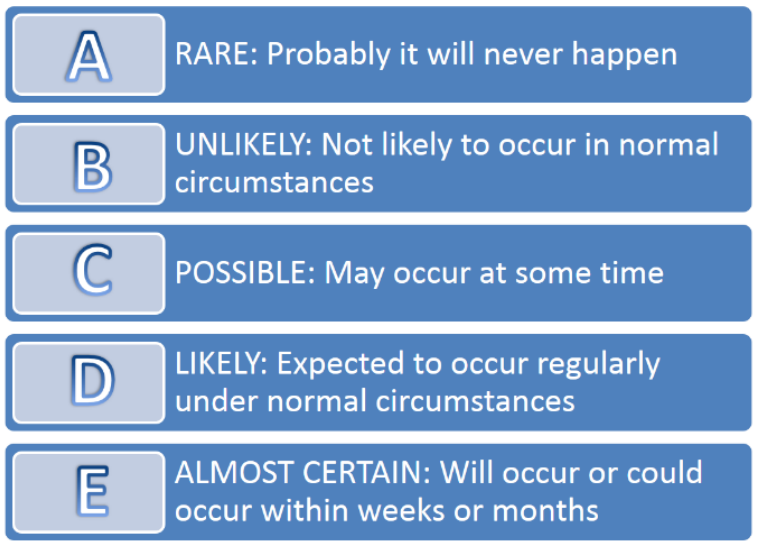

(b)

Figure 3. (a) Scale of consequences according to the economic impact of losses defined by mining insurance companies; (b) Likelihood rating.

\subsubsection{Risk Evaluation}

Risk evaluation involves comparing the estimated level of risk with risk criteria defined when the context was established to determine the class's significance and type of risk [20]. Risk evaluation uses the understanding of risk obtained during risk analysis to make decisions about future actions. Ethical, legal, financial, and other considerations, including perceptions of risk, are also inputs to the decision.

Decisions may include whether a risk needs treatment, the priorities for treatment, whether an activity should be undertaken, and which of several paths should be followed.

A matrix was drawn with consequence on one axis and probability of their occurrence on the other axis (Figure 4a). The risk levels assigned to the cells depended on the definitions for the probability/consequence scales. The matrix from IEC/ISO 31010 [19] was used and is presented in Figure $4 \mathrm{~b}$.

To rank the risks, it was necessary to find the consequence descriptor that best fit the situation, and then to define the probability with which those consequences would occur. Then, the level of risk was read from the matrix. The residual risk was also determined using the same risk matrix after the proposed treatment actions were identified. 


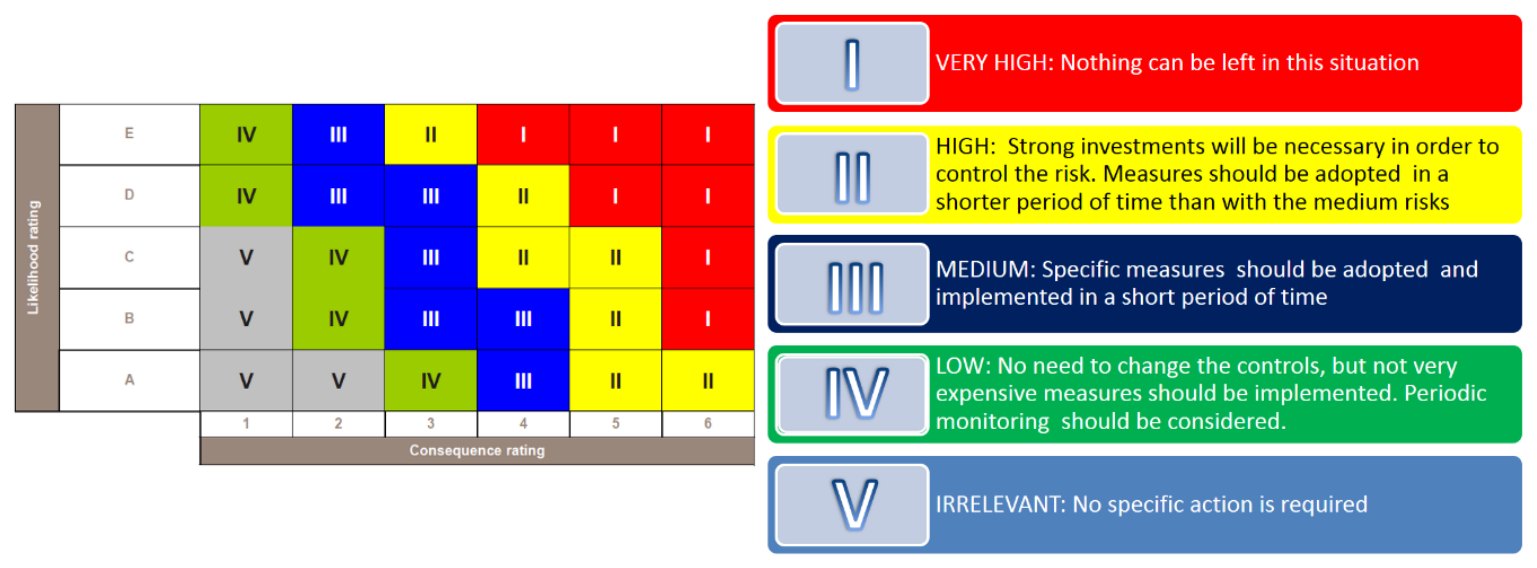

(a)

(b)

Figure 4. (a) Probability criteria matrix (likelihood versus consequence); (b) Risk levels assigned to the cells.

\subsubsection{Risk Treatment}

Finally, suppose that the risk evaluations determined that the level of risk was not acceptable and that there was a need to reduce the risk further. In this case, treatment options in the form of new or additional control measures should be identified. When considering what other control measures should be implemented, it is essential to consider the hierarchy of risk control adopted in many regulatory approaches.

\section{Results}

\subsection{Risk Identification}

The events or effects that must be considered based on the context of the Mosquitera and Pumarabule mines are the modification of flows, including the appearance of humid zones and floods, violent or not; pollution of underground aquifers; and flooding of other mines. Pollution of surface waters is not considered in this analysis.

\subsection{Risk Analysis}

\subsubsection{Modification of Flows}

Three different causes were considered to determine the risks affecting the modification of floods, i.e., natural causes, technical causes, and human causes. The tree diagram that shows the possible and likely reasons is presented in Figure 5. Technical and human causes were considered together to simplify the model, and the risks were reduced to one that comprises all the rest, i.e., pumping failure, which can be regarded to be an effect of the rest of the causes (control system failure, mechanical failure, electrical failure, sabotage, and maintenance errors).

First, to analyze the risk associated with heavy rainfall, an analysis of the pumping system installed in the shafts has to be developed. Five pumps were installed in the shafts (three pumps in Mosquitera and two pumps in Pumarabule) to maintain the security level, i.e., in the Mosquitera mine, three $37 \mathrm{~kW}$ pumps with a nominal flow of $225 \mathrm{~m}^{3} / \mathrm{h}$ each; in the Pumarabule mine, two $55 \mathrm{~kW}$ pumps with a nominal flow of $240 \mathrm{~m}^{3} / \mathrm{h}$ each. Pumarabule is used as an auxiliary pumping facility for Mosquitera, so in Pumarabule, there is pumping when Mosquitera pumps cannot maintain the safe water level in the mines (Figure 6).

From the historical pumping data that was available from the Mosquitera and Pumarabule mines (since 1995), the following data were extracted:

- $\quad$ Maximum pumped volume for one year of $2,926,470 \mathrm{~m}^{3}\left(334 \mathrm{~m}^{3} / \mathrm{h}\right)$;

- $\quad$ Average pumped volume for one year of $2,499,260 \mathrm{~m}^{3}\left(285 \mathrm{~m}^{3} / \mathrm{h}\right)$;

- Maximum pumping value of $15,979 \mathrm{~m}^{3} /$ day $\left(666 \mathrm{~m}^{3} / \mathrm{h}\right)$. 


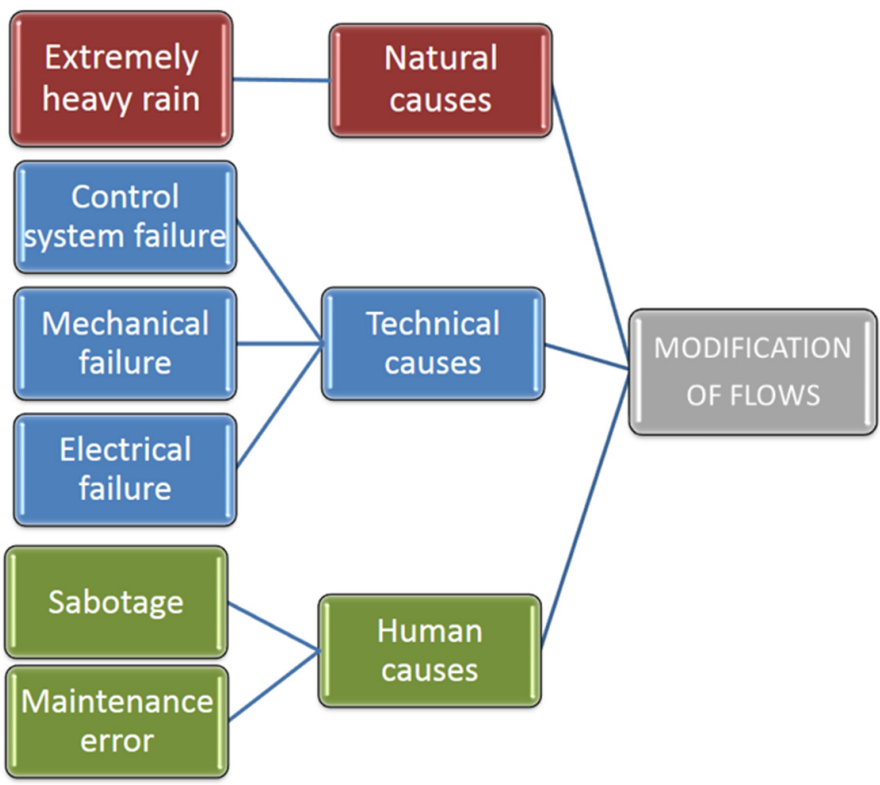

Figure 5. Tree formulation of the cause-and-effect analysis for the modification of flow effects.

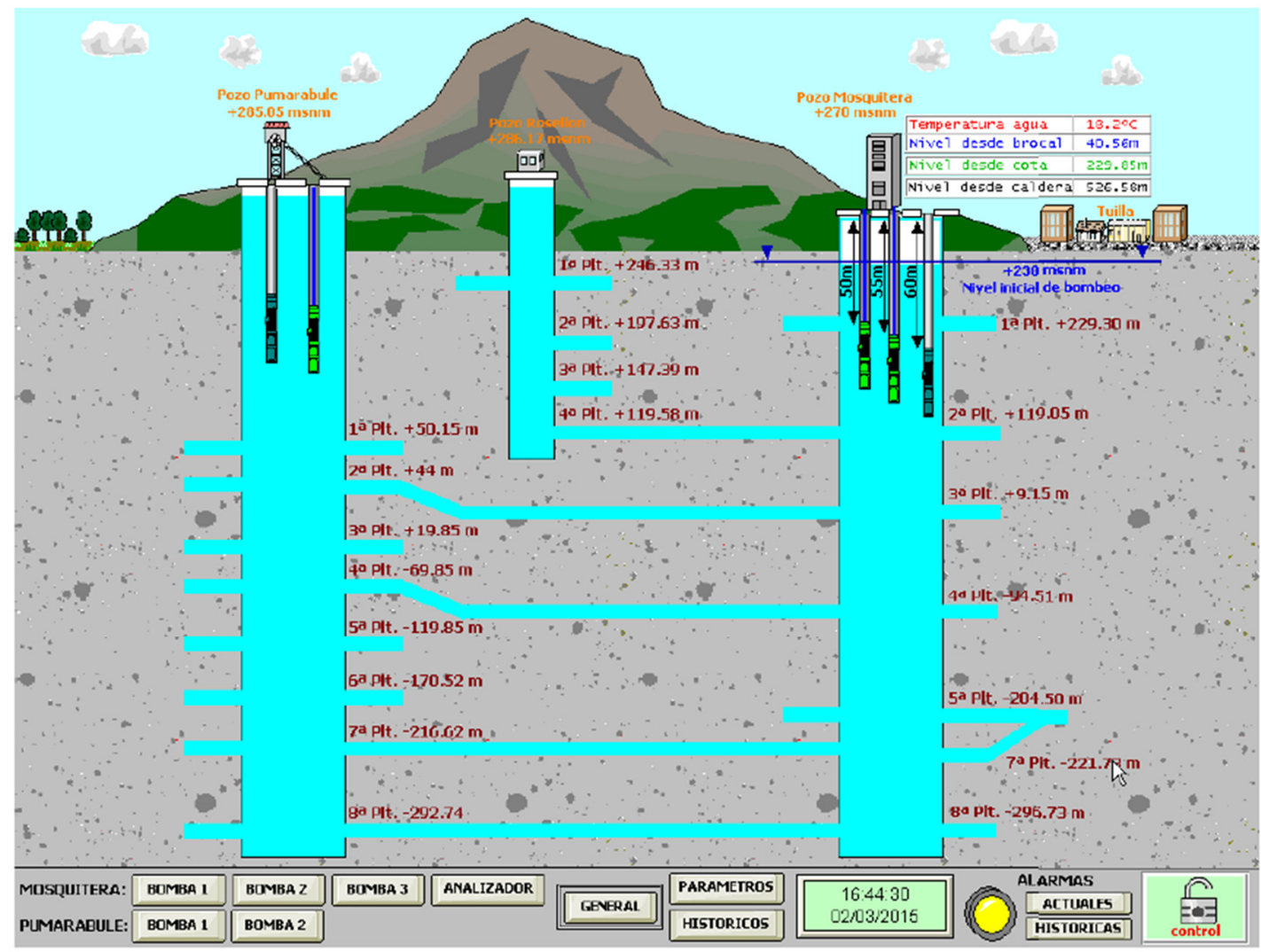

Figure 6. Pumping system installed in the Mosquitera and Pumarabule mines (courtesy of HUNOSA).

Using precipitation data from the Oviedo station, which is located about $15 \mathrm{~km}$ from the study area, the following values were extracted:

- $\quad$ Maximum precipitation in one day of $109.5 \mathrm{~mm}$ (6 May 1975);

- $\quad$ Maximum precipitation in one month of $340.3 \mathrm{~mm}$ (October 1992);

- $\quad$ Average precipitation in one year of $960 \mathrm{~mm}$;

- $\quad$ Average monthly precipitation (mm) of Jan (84), Feb (81), Mar (78), Apr (100), May (82), Jun (57), Jul (45), Aug (56), Sep (66), Oct (98), Nov (115) and Dec (98). 
The appropriate hydraulic limits were delimitated first to determine the water balance of the area. The lateral extension of the model is constrainted by geological features, water divides, and unaltered massif between mines with no direct connection. The main settings controlling the extension of the model are faults and impervious levels in the stratigraphic sequence. Surface water divides were also considered. The extension of the model gives a total of $25.4 \mathrm{~km}^{2}$ [20].

Ordóñez et al. [21] suggested that the total infiltration in the Mosquitera and Pumarabule mine areas ranges between 22 and $26 \%$ of the effective rain infiltration, which is approximately $42 \%$ of the complete infiltration. Thus, the effective infiltration is within the range of $9.2-10.8 \%$. An average of $10 \%$ of effective infiltration for our estimations was then used.

As the average rain in one year was $960 \mathrm{~mm}, 10 \%$ is $96 \mathrm{~mm} /$ year, equivalent to $2,438,000 \mathrm{~m}^{3}$. On the one hand, the pumping, during 2015, was 2,060,640 $\mathrm{m}^{3}\left(235 \mathrm{~m}^{3} / \mathrm{h}\right)$ in Mosquitera and 509,400 $\mathrm{m}^{3}\left(58 \mathrm{~m}^{3} / \mathrm{h}\right)$ in Pumarabule, giving a total of 2,570,040 $\mathrm{m}^{3}$ $\left(293 \mathrm{~m}^{3} / \mathrm{h}\right)$, which implies an excellent correlation. On the other hand, the runoff or the return flow, although unknown, would be minimal.

In the case of heavy rainfall, the following three cases were considered within a yearly water balance:

- Two times the average precipitation in one year is $1920 \mathrm{~mm} /$ year, which is equivalent to an effective infiltration of $192 \mathrm{~mm} /$ year, thus, representing 4,876,800 $\mathrm{m}^{3}\left(557 \mathrm{~m}^{3} / \mathrm{h}\right)$.

- Three times the average precipitation in one year is $2880 \mathrm{~mm} /$ year, which is equivalent to an effective infiltration of $288 \mathrm{~mm} /$ year, thus, representing 7,315,200 $\mathrm{m}^{3}\left(835 \mathrm{~m}^{3} / \mathrm{h}\right)$.

- Four times the average precipitation in one year is $3840 \mathrm{~mm} /$ year, which is equivalent to an effective infiltration of $384 \mathrm{~mm} /$ year, representing 9,753,600 $\mathrm{m}^{3}\left(1113 \mathrm{~m}^{3} / \mathrm{h}\right)$.

As the pumping system's total nominal flow is $1155 \mathrm{~m}^{3} / \mathrm{h}$, the system is completely capable of pumping four times the average precipitation in one year.

Developing now a monthly water balance, the maximum precipitation since 1920 was $340.3 \mathrm{~mm} / \mathrm{month}$, which is equivalent to an effective infiltration of $34.03 \mathrm{~mm} / \mathrm{month}$, thus, representing $864,362 \mathrm{~m}^{3}\left(1162 \mathrm{~m}^{3} / \mathrm{h}\right)$.

With a total nominal flow of $1155 \mathrm{~m}^{3} / \mathrm{h}$, the system is almost capable of pumping this amount of effective infiltrated water.

Addressing pumping failure, Figure 7 presents the various stages that were monitored during the flooding of the Mosquitera and Pumarabule mines and the Candin river situation in its lower elevation.

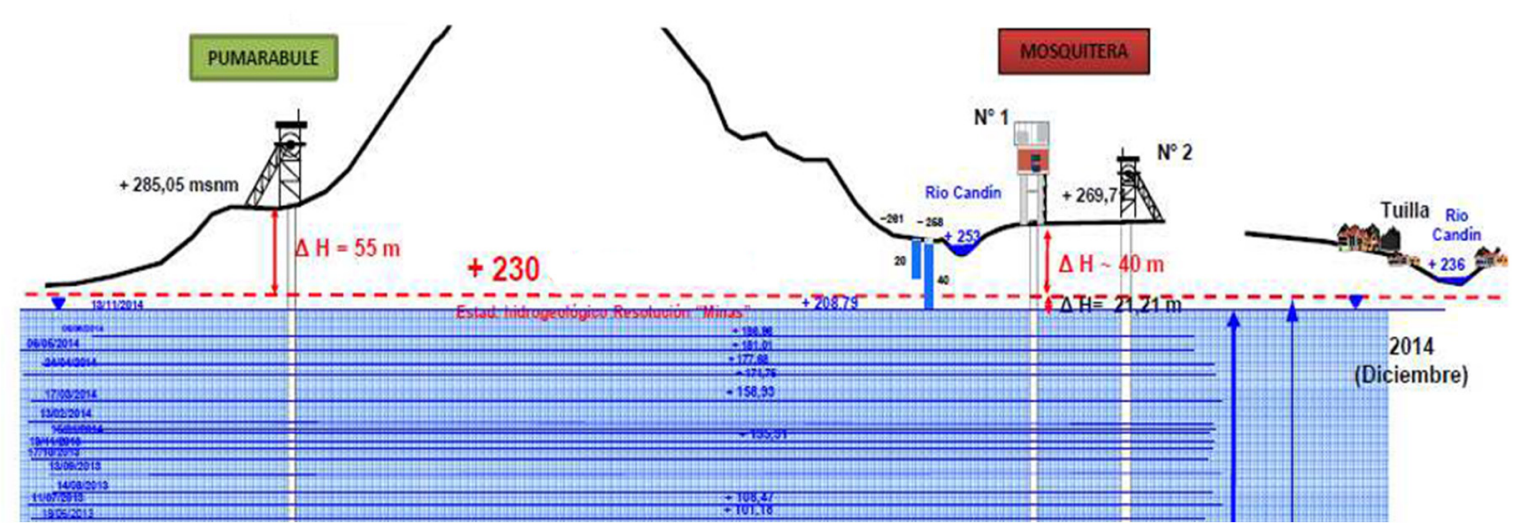

Figure 7. Water rebound monitoring in the Mosquitera and Pumarabule mines (courtesy of HUNOSA).

When HUNOSA stopped the pumping in the Mosquitera and Pumarabule mines on 26 October 2010, the groundwater rebound took about four years. The total amount of flooding days was 1424 , with a flooded range of 498.88 , giving an average flooding speed of $0.350 \mathrm{~m} /$ day. 
In the case of a complete pumping failure, for example, in the case of an electrical failure, a system control failure, or sabotage, it would take almost three days for the water level to increase by one meter, with the average flooding speed of $0.350 \mathrm{~m} /$ day. The lowest point in the area is the Candín river near the village of Tuilla, situated at 236 m.a.s.l. This figure is only one meter above the permitted flooding level by the mining authority, i.e., 235 m.a.s.l. Moreover, there is no buffer volume, such as an intermediate unflooded level in Mosquitera to impede fast discharge to the surface (Figure 5).

The area around Tuilla village may be compromised in terms of groundwater flooding if there is a sudden increase in water level.

\subsubsection{Pollution of Underground Aquifers}

In the specific case of HUNOSA, the Asturian Mining Authority requested to control the quality of water in the Mosquitera and Pumarabule mines through quarterly samples of the following parameters: total Iron; sulphides; electric conductivity; $\mathrm{pH}$; and suspended solids. Some of the analysis made at the Mosquitera and Pumarabule mines are presented in Table 1.

Table 1. Water quality analyses at the Mosquitera and Pumarabule mines.

\begin{tabular}{|c|c|c|c|c|c|c|}
\hline Sample Location & Date & $\mathrm{pH}$ & $\begin{array}{l}\text { Suspended Solids } \\
(\mathrm{mg} / \mathrm{L})\end{array}$ & $\begin{array}{c}\text { Conductivity } \\
\left(\mu \mathrm{S} / \mathrm{cm} \text { at } 20^{\circ} \mathrm{C}\right)\end{array}$ & $\begin{array}{l}\text { Total Iron } \\
(\mathrm{mg} / \mathrm{L})\end{array}$ & $\begin{array}{l}\text { Sulphates } \\
\text { (mg/L) }\end{array}$ \\
\hline Mosquitera & $22 / 12 / 2014$ & 7.5 & $<5.0$ & 808 & 0.2 & 80 \\
\hline Mosquitera ${ }^{1}$ & $11 / 05 / 2015$ & 7.1 & & 2700 & & \\
\hline Mosquitera & $05 / 06 / 2015$ & 7.6 & 21 & 2390 & 10.2 & 600 \\
\hline Mosquitera & $14 / 07 / 2015$ & 7.4 & $<5$ & 1598 & 2.9 & 340 \\
\hline Mosquitera & $26 / 08 / 2015$ & 7 & 22 & 3450 & 9.3 & 600 \\
\hline Pumarabule & $06 / 02 / 2015$ & 6.9 & 21 & 1350 & 1.9 & 530 \\
\hline Pumarabule $^{1}$ & $11 / 05 / 2015$ & 7 & & 1551 & & \\
\hline Pumarabule & $05 / 06 / 2015$ & 7.7 & 22 & 4000 & 7.4 & 500 \\
\hline Pumarabule & $14 / 07 / 2015$ & 7.2 & 19 & 1783 & 6.9 & 580 \\
\hline
\end{tabular}

\footnotetext{
${ }^{1}$ In situ analyses.
}

When comparing these results with the limits established by Directive 2006/44/E.C. [16], both $\mathrm{pH}$ and suspended solids are consistently below the limits. In the case of Polish threshold limit values for water contaminants from industry including water from coal mine drainage [19], conductivity $\left(\mu \mathrm{S} / \mathrm{cm}\right.$ at $\left.20^{\circ} \mathrm{C}\right)$ and sulphates $(\mathrm{mg} / \mathrm{L})$ present anomalous values (two times in the case of conductivity and four times in the case of sulphates). Regarding total iron (mg/L) content, although only one abnormal value is observed, it is possible to establish a correlation between total iron, sulphates, and conductivity.

Figure 8 presents the values of conductivity $\left(\mu \mathrm{S} / \mathrm{cm}\right.$ at $\left.20^{\circ} \mathrm{C}\right)$, sulphates $(\mathrm{mg} / \mathrm{L})$, and total iron of the analysis made at the Mosquitera mine, without considering in situ analyses.

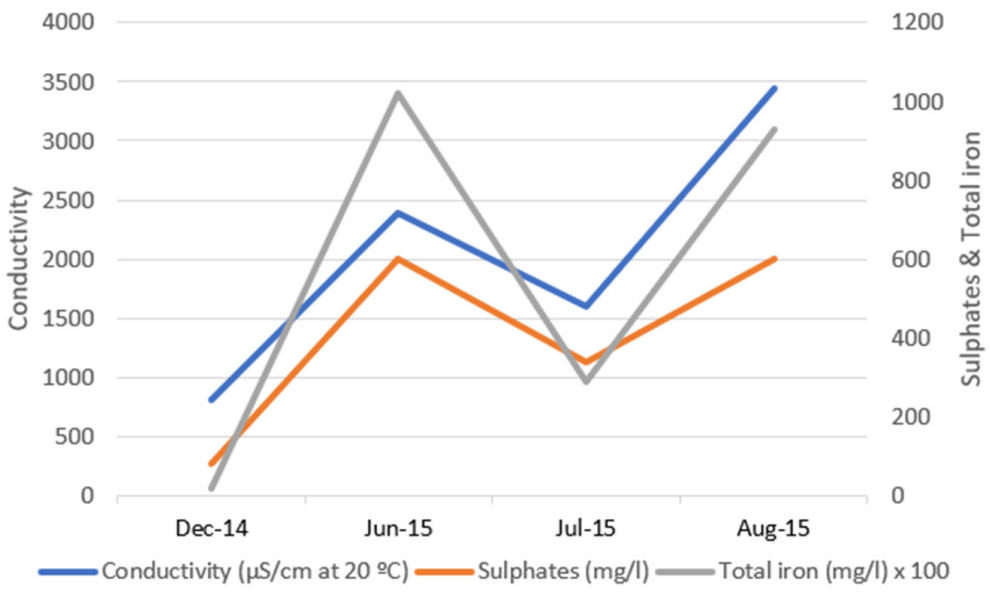

Figure 8. Conductivity, sulphates, and total iron of the analysis made at the Mosquitera mine. 
There is only one water point (used for industrial purposes) close to the study area in which the interaction with the mine water has to be studied, since the levels of the remaining aquifers are higher than the mine water level (235 m.a.s.1.).

\subsubsection{Flooding of Other Mines}

The area of study has been intensively mined over the decades. The Mosquitera and Pumarabule mines are isolated in terms of direct underground access for people and materials. There is no known working road or coal seam working panel that communicates these mines with other exploitations located at the southern or northern limits [20]. However, the proximity with other underground exploitations requires an evaluation of the possible hydraulic connection, although the unaltered massif is considered to have very low permeability, with hydraulic conductivity values lower than $10^{-7} \mathrm{~m} \cdot \mathrm{s}^{-1}$, reaching $5 \times 10^{-6} \mathrm{~m} \cdot \mathrm{s}^{-1}$ in fractured zones [21].

Three mine systems are located close to the Mosquitera and Pumarabule mines, except for the Venturo mine, which is connected to Sotón (an underground mine museum) and the other mines are located in the Nalón River valley, which are at higher topographic elevation or recovering the water level, therefore, they are not expected to be affected by flooding in the Mosquitera and Pumarabule mines.

A hydraulic gradient from the Mosquitera and Pumarabule mines to the Venturo mine is assumed; however, if this occurred, the very low permeability of the massif would mean very low water flow, thus, the risk is irrelevant.

\subsection{Risk Evaluation}

\subsubsection{Modification of Flows}

In the case of a change of flows, the likelihood was rated with a " $\mathrm{C}$ ", as floods caused by heavy rainfall and pump failures may occur at some time, but they are not expected to occur regularly under normal circumstances.

The facts leading to this conclusion for heavy rainfall were:

- The pumping system is completely capable of pumping four times the average precipitation in one year.

- The pumping system is "almost" capable of pumping the maximum precipitation of one month in 1920. Nevertheless, a sudden rise may occur as no buffer volume such as an intermediate unflooded level is available in Mosquitera to impede fast discharge to the surface.

- The very low permeability of the unaltered carboniferous massif reduces the possibility of groundwater flooding, but groundwater levels should be monitored to prevent further impacts.

- The risk does not occur regularly.

The facts leading to this conclusion for pumping failure were:

- There are five pumps installed; therefore, in one of the pumps fails, the pump capacity would only be reduced by approximately $20 \%$.

- In the case that all of them fail to work, for example, in the case of an electrical failure, a system control failure, or sabotage, it would take almost three days for the water level to increase by one meter, with the average flooding speed of $0.350 \mathrm{~m} / \mathrm{day}$. Nevertheless, it must be considered again that no buffer volume such as an intermediate unflooded level is available in Mosquitera to impede fast discharge to the surface.

Suppose a modification of the river flow or an uplift of the river occurs, in this case, the impact would be moderate (monetary loss can be estimated between 60,000 Euros and 300,000 Euros), and thus specific measures should be adopted and implemented in a short period of time.

Figure 9 presents the risk analysis for the modification of flows. The risk level is, then, classified as medium, therefore, specific measures should be adopted and implemented quickly. 


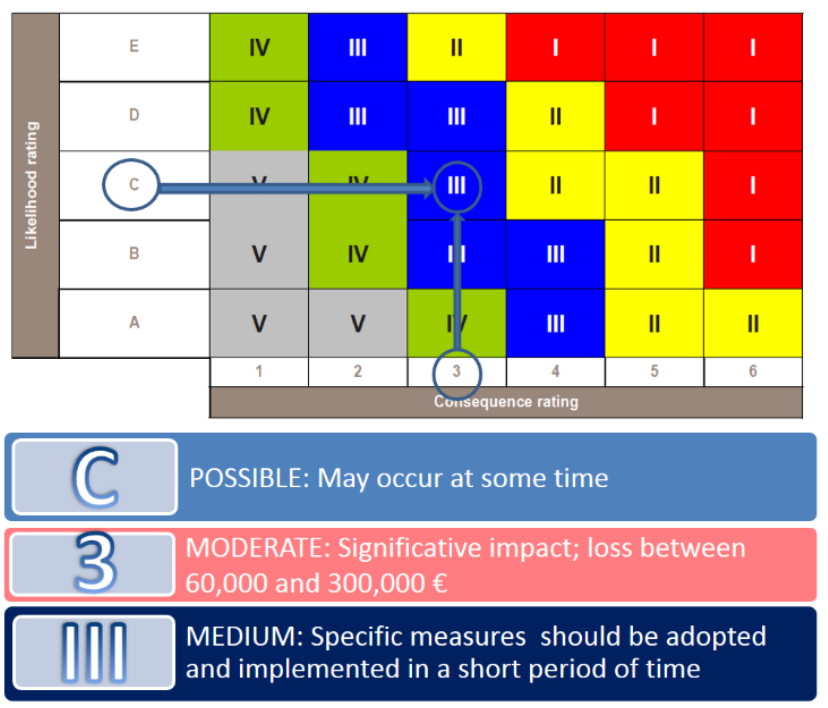

Figure 9. Risk analysis for modification of flows.

\subsubsection{Pollution of Underground Aquifers}

In the case of pollution of underground aquifers, the likelihood was rated with an " $\mathrm{E}$ ", as the impact on water is very likely to occur, even if new drilling activities that can connect different aquifers are made in the area [22,23]. However, the impact would be minimal (monetary loss can be estimated between 10,000 Euro and 60,000 Euro). There is only one underground aquifer that may be polluted and used for industrial purposes.

Figure 10 presents the risk analysis for pollution of underground aquifers. Then, the risk level is classified again as medium, therefore, specific measures should be adopted and implemented quickly.
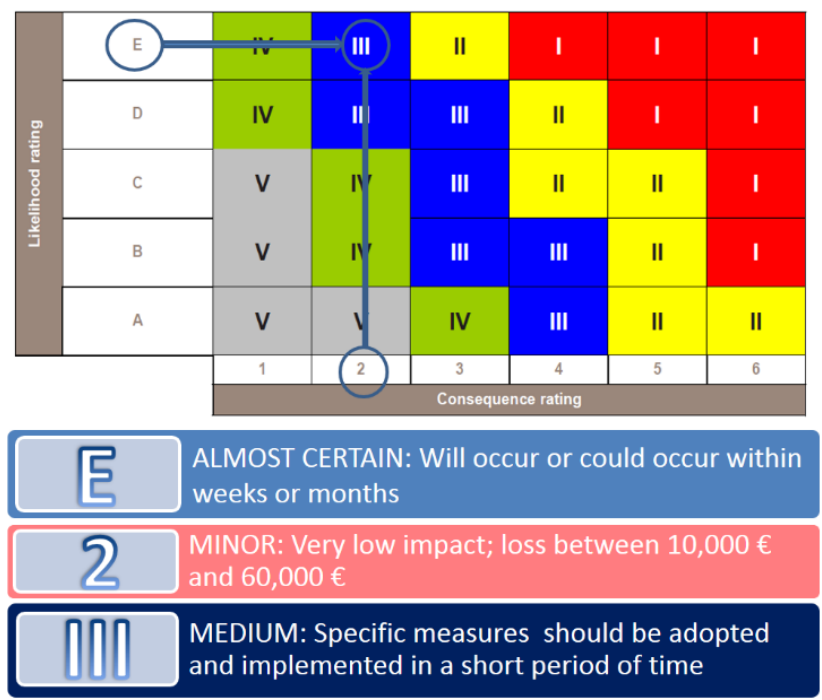

Figure 10. Risk analysis for pollution of underground aquifers.

\subsection{Risk Treatment}

\subsubsection{Modification of Flows}

According to the risk analysis, the proposed treatment was to develop additional piezometric controls in the area with a higher risk of floods, especially South of Tuilla, near Mosquitera 2. The reason is that the two piezometers already installed (Figure 7) are in a more elevated area, in the quaternary deposits near Mosquitera 1, showing no connection with the Carboniferous aquifer, therefore, perched aquifers were not included in the conceptual model. 
In addition, installation of an independent powered water level alarm sensor in those piezometers, ideally connected by phone with the person in charge of the pumping system, could be something that should complement these specific measures.

A time series of pumping rates and levels in the mine should be provided with a higher sampling frequency (e.g., daily better than monthly) using these piezometers. The estimation of recharge values is of extreme importance to assess the aquifer's infiltration and to relate head variations with rain data.

Finally, the installation of at least one weather station (which is relatively inexpensive) for providing daily data of rainfall and temperature on the study area would give valuable information linked to high-frequency series of pumping/levels in the mine.

\subsubsection{Pollution of Underground Aquifers}

Regarding the pollution of underground aquifers, as the water point that may be polluted is used for industrial purposes, the impact would be minimal (monetary loss can be estimated between 10,000 Euro and 60,000 Euro). Still, specific measures should be adopted and implemented in a short period.

The specific measure to adopt is undertaking a hydro chemical laboratory control analysis and head monitoring at this water point used by industry. The periodicity of the controls or the possibility to stop them would depend on the characteristics of the water required by the industry, something that should to be further evaluated.

\section{Discussion}

The cost for the installation of three piezometers near Mosquitera 2, one under the water level (approximately $40 \mathrm{~m}$ ), the second over the water level (approximately $30 \mathrm{~m}$ ), and the third one within the Quaternary (approximately $10 \mathrm{~m}$ ) to detect influences from the river or from hanging or shallow aquifers, is presented in Table 2 . The second treatment option is to install independently powered water level alarm sensors in those piezometers, ideally connected by phone with the person in charge of the pumping system, which would complement these specific measures, and the cost of this is also presented in Table 2. Finally, the costs of the installation of one weather station providing daily data of rain and temperature on the study area, the periodic monitoring of the piezometers and the weather station, and the yearly cost of water analysis for at least five years, are also presented in Table 2.

Table 2. Investments and maintenance costs.

\begin{tabular}{cc}
\hline Investments and Maintenance & Cost \\
\hline Piezometer installation $(80 \mathrm{~m} \times 180 € / \mathrm{m})$ & $14,400 €$ \\
Probe water level meter $(30 \mathrm{~m})$ & $400 €$ \\
3G SMS control and monitoring with solar panel & $1000 €$ \\
Yearly line maintenance & $600 €$ \\
Wireless weather station & $1000 €$ \\
Yearly monitoring of piezometers and station & $2400 €$ \\
Yearly cost of water analysis $(250 € \times 12)$ & $3000 €$ \\
\hline
\end{tabular}

Figure 11 represents the investments that have to be made at the beginning of the treatment period.

Several considerations should be made before starting the calculation of the following net present value (NPV):

- Instead of what is usual in this kind of analysis and to simplify the calculations, constant euros of 2020 were considered, and not current euros as some might expect. The reason is not to take inflation into account, as the growth in prices is assumed to be the same level as the expected inflation rate. Thus, by doing this, the costs would remain stable during the years considered for the calculation. 
- As HUNOSA is a state company, the discount rate used should be obtained from the cost of a loan in the banks for this kind of company. It is possible to estimate the discount rate between 7 and $7.5 \%$. If average inflation is expected between 2 and $2.5 \%$, then, the constant discount rate would be $7.5 \%-2.5 \%=5 \%$, which is assumed not to change with time.

- A period of 20 years was considered without any residual value, as it was estimated that there would be no environmental risks to be treated beyond that date. Moreover, considering the small cash flow of the last years, and even considering more years, there would be almost no effect on the NPV.

- As HUNOSA is a company, all calculations exclude value added tax (VAT).

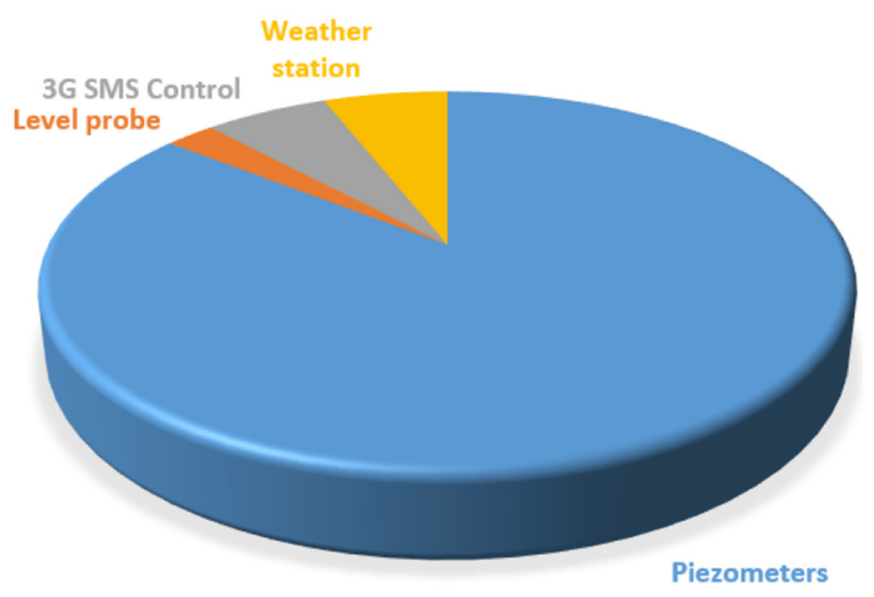

Figure 11. Investments at the beginning of the treatment period.

In Figure 12, the cash flow for the future 20 years is presented. After the fifth year, it should be possible to stop with the hydrochemical laboratory control analysis. That is the reason for the reduction of the cash flow from that year.

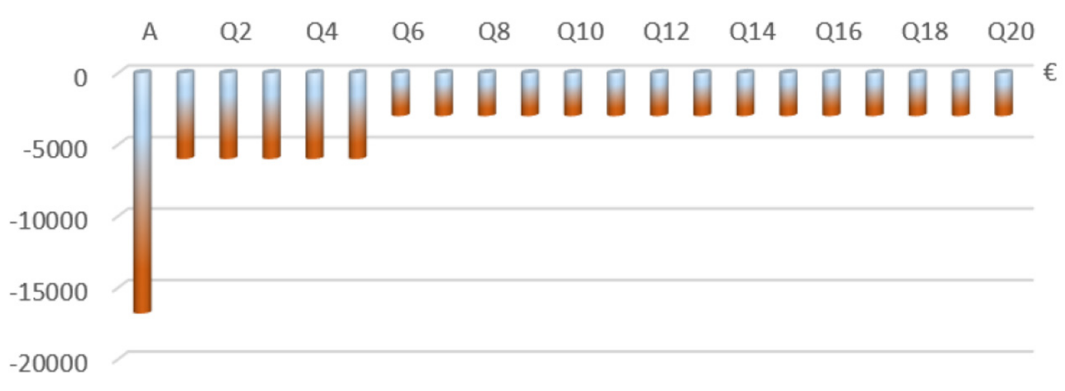

Figure 12. Cash flow for the future 20 years.

The expression to calculate the NPV (in fact cost present value, as there are no positive cash flows) to determine the financial provisions required for closure and post closure regarding groundwater risks is as follows:

$$
N P V=-A+\frac{Q_{1}}{(1+i)}+\frac{Q_{2}}{(1+i)^{2}}+\frac{Q_{3}}{(1+i)^{3}}+\ldots+\frac{Q_{20}}{(1+i)^{20}}
$$

Using the previous value, the following NPV is obtained:

$$
A=14,400 €+400 €+1000 €+1000 €=16,800 €
$$

$$
\begin{gathered}
\mathrm{Q} 1, \mathrm{Q} 2, \mathrm{Q} 3, \mathrm{Q} 4, \mathrm{Q} 5=-600 €-2400 €-3000 €=-6000 € \\
\mathrm{NPV}=-67,175 €
\end{gathered}
$$


To estimate which cost the NPV is more sensitive, a sensitivity analysis was developed with $\pm 10 \%$ in every variable. The program that was used for the sensitivity analysis was TopRank, from Palisade Corporation (Ithaca, NY, USA). The spider graph obtained is presented in Figure 13.

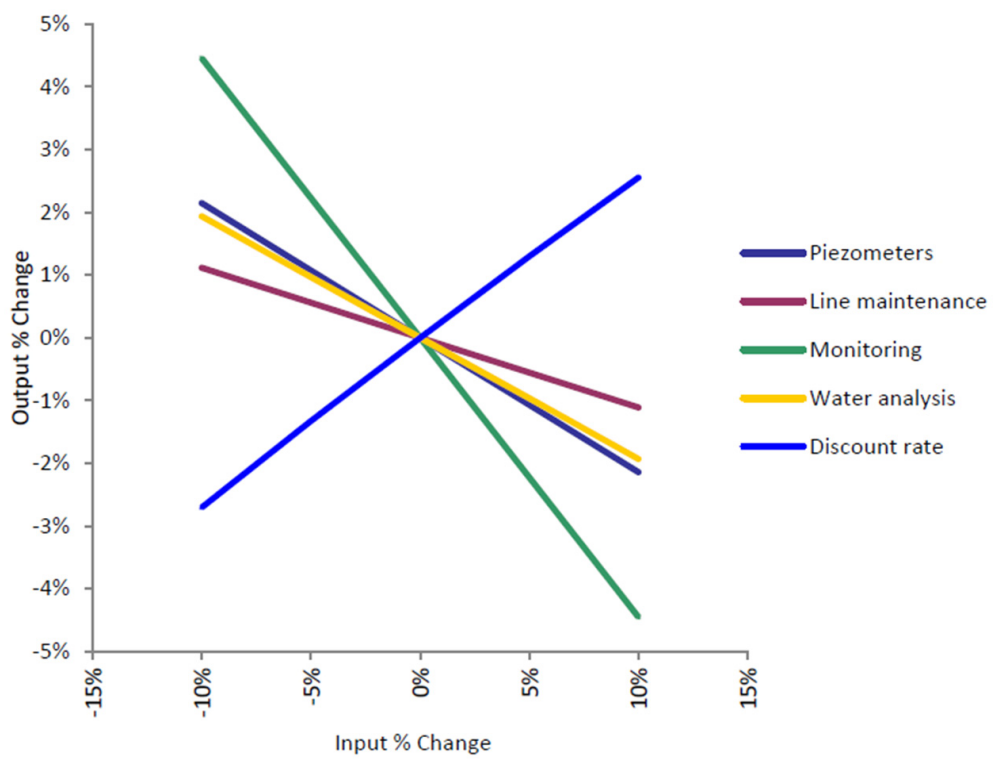

Figure 13. Spider graph for the net present value (NPV) calculation variables.

The NPV is more sensitive to the yearly cost of monitoring the piezometers and the station, the discount rate, and in third place, the piezometer installation.

The yearly costs of monitoring the piezometers can be more rigorously modeled using an inverse Gaussian distribution centered in 2300 Euro with parameters $\mathrm{Mu}=240$ and Lambda $=120$, to represent possible higher prices but with a low probability.

In addition, no possible discount rate variations were considered, but a triangular function modeled the piezometer installation with parameters $(13,900,14,400$, and 15,400).

The Monte Carlo analysis is run and the NPV is as presented in Figure 14. The NPV distribution obtained has a mean of $-68,910$ Euro, a minimum of -105,971 Euro, a maximum of $-65,068$ Euro and a standard deviation of 4169 Euro. The program that was used for the uncertainty analysis was @Risk, from Palisade Corporation (Ithaca, NY, USA).

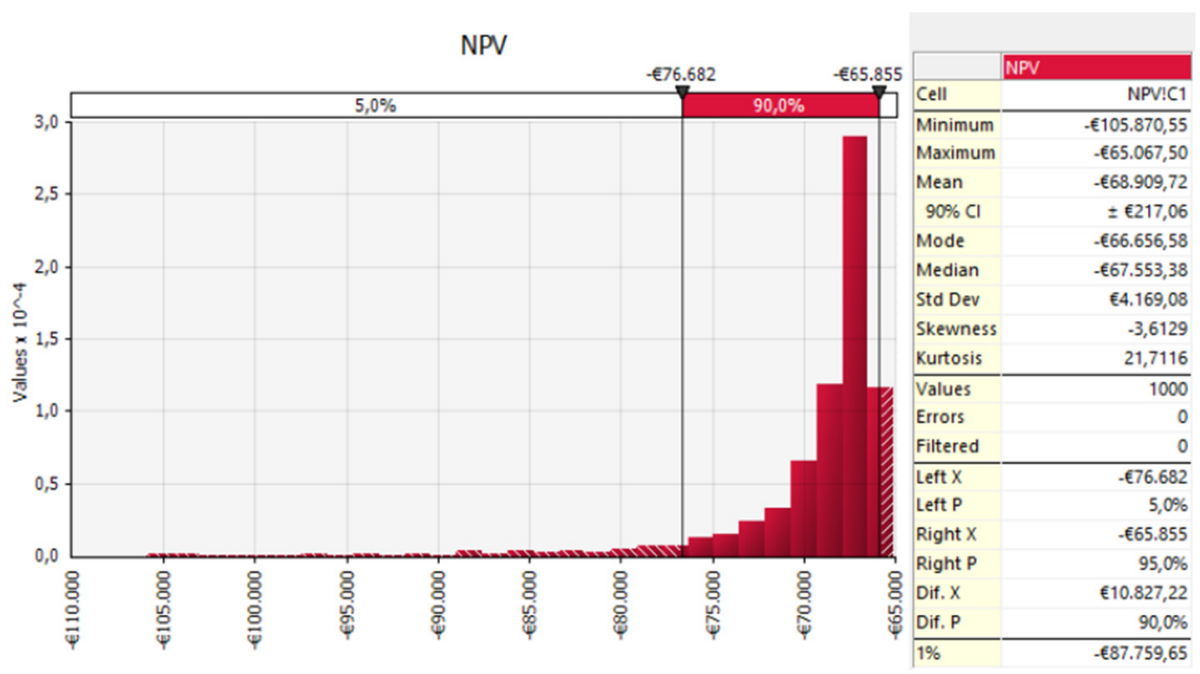

Figure 14. Monte Carlo analysis of the NPV. 


\section{Conclusions}

To undergo the groundwater risk assessment in the context of an underground coal mine closure and the economic evaluation of the proposed treatments in the Mosquitera and Pumarabule mines, properties of Hulleras del Norte, S.A. (HUNOSA) in Spain, the first step was to identify the risks. The events or effects that must be considered based on these mines' context were a modification of flows, including the appearance of humid zones and floods, violent or not; pollution of underground aquifers; and flooding of other mines. Pollution of surface waters was not considered in the analysis.

Secondly, a risk analysis was conducted. Technical and human causes were considered together, and the risks relevant to the modification of flows were reduced to two, i.e., pumping failure, heavy rainfall. Regarding pollution of underground aquifers, a water analysis campaign was developed and showed that conductivity and sulphates present anomalous values with total iron. Nevertheless, there is only one water point close to the study area in which the interaction with the mine water should have to be studied, as the level of the rest of aquifers is higher than the mine water level. Finally, due to the very low permeability of the massif, the risk of flooding of other mines is irrelevant.

Next, a risk evaluation was addressed. If a modification of the river flow or an uplift of the river occurs, the impact would be moderate, with a monetary loss estimated between 60,000 Euro and 300,000 Euro. Thus, specific measures should be adopted and implemented in a short period of time. In the case of pollution of underground aquifers, the impact would be minimal, with a monetary loss estimated between 10,000 Euro and 60,000 Euro. Only one underground aquifer that may be polluted is used for industrial purposes.

According to the risk analysis, first, the proposed treatments should be to develop additional piezometric controls in the area with a higher risk of floods. Secondly, independently powered water level alarm sensor should be installed in the piezometers, ideally connected by phone with a person in charge of the pumping system, as well as at least one weather station should include lodging for a person to provide daily rainfall and temperature data on the study area. In the case of pollution of other aquifers, a hydrochemical laboratory control analysis and head monitoring at this water point used by the industry should be developed. The periodicity of the controls or the possibility to stop them would depend on the characteristics of the water required by the industry, something that should to be further evaluated.

Finally, treatment costs and monitoring were evaluated to estimate the financial provisions needed to mitigate groundwater risks during an underground coal mine closure. An amount of 70,000 Euro was calculated as necessary to minimize these risks, which can be considered to be quite a low provision.

Author Contributions: Conceptualization, G.F.V., A.D., F.J.I.R., and I.T.; methodology, G.F.V. and I.T.; software, G.F.V., A.D., and F.J.I.R.; validation, G.F.V. and A.D.; formal analysis, G.F.V., F.J.I.R., and I.T.; investigation, G.F.V., A.D., and F.J.I.R.; resources, G.F.V., A.D., and F.J.I.R.; data curation, G.F.V. and A.F.; writing—original draft preparation, G.F.V. and A.D.; writing—review and editing, G.F.V. and A.F.; visualization, G.F.V., F.J.I.R., and I.T.; supervision, G.F.V. and A.D.; project administration, G.F.V. and A.F. All authors have read and agreed to the published version of the manuscript.

Funding: The work presented in this paper has been developed within the MERIDA project (Management of Environmental Risks During and After mine closure) supported by the Research Fund for Coal and Steel (RFCS), European Commission, under the contract no. RFCR-CT-2015-00004, and by the Polish Ministry of Science and Higher Education under the contract no. 3610/FBWiS/2016/2.

Institutional Review Board Statement: Not applicable.

Informed Consent Statement: Not applicable.

Data Availability Statement: Not applicable.

Conflicts of Interest: The authors declare no conflict of interest. 


\section{References}

1. Laurence, D. Establishing a sustainable mining operation: An overview. J. Clean. Prod. 2011, 19, 278-284. [CrossRef]

2. Didier, C. Postmining Management in France: Situation and Perspectives. Risk Anal. 2009, 29, 1347-1354. [CrossRef] [PubMed]

3. Heikkinen, P.M.; Noras, P.; Salminen, R.; Mroueh, U.M.; Vahanne, P.; Wahlström, M.; Kaartinen, T.; Juvankoski, M.; Vestola, E.; Mäkelä, E.; et al. Mine Closure Handbook: Environmental Techniques for the Extractive Industries. Geological Survey of Finland, Technical Research Center of Finland; Outokumpu Oyj and Finnish Road Enterprise and Soil and Water Ltd.: Vammalan Kirjapaino Oy, Finland, 2008. Available online: http:/ / arkisto.gtk.fi/ej/ej74.pdf (accessed on 3 November 2020).

4. Pulles, W. Best Practice Guideline G4: Impact Prediction; Department of Water Affairs and Forestry: Pretoria, South Africa, 2008. Available online: http:/ / www.bullion.org.za/documents/g4-impact-prediction.pdf (accessed on 4 November 2020).

5. Australian Department of Industry, Tourism and Resources. Mine Closure and Completion; Australian Government: Canberra, Australia, 2006. Available online: http://www.minerals.org.au/file_upload/files/resources/enduring_value/mine_closure.pdf (accessed on 5 November 2020).

6. Cowan, W.R.; Mackasey, W.O.; Robertson, J. The Policy Framework in Canada for Mine Closure and Management of Long-Term Liabilities; National Orphaned-Abandoned Mines Initiative: Ottawa, ON, Canada; Cowan Minerals Ltd.: Sudbury, ON, Canada, 2010. Available online: http:/ / www.abandoned-mines.org/pdfs/PolicyFrameworkCanforMinClosureandMgmtLiabilities.pdf (accessed on 6 November 2020).

7. Research Fund for Coal and Steel (RFCS) Council Decision of the 29th of April 2008 on the adoption of the Research Programme of the Research Fund for Coal and Steel and on the multiannual technical guidelines for this programme (2008/376/E.C.). Off. J. Eur. Union 2008, L 130, 7-17.

8. MERIDA Project Management of Environmental Risks during and after Mine Closure. Research Fund for Coal and Steel; Contract No. RFCR-CT-2015-00004; European Commission: Brussels, Belgium, 2019.

9. Riesgo Fernández, P.; Rodríguez Granda, G.; Krzemień, A.; García Cortés, S.; Fidalgo Valverde, G. Subsidence versus natural landslides when dealing with property damage liabilities in underground coal mines. Int. J. Rock Mech. Min. Sci. 2020, 126. [CrossRef]

10. Duda, A.; Krzemień, A. Forecast of methane emission from closed underground coal mines exploited by longwall mining-A case study of Anna coal mine. J. Sustain. Min. 2018, 17, 184-194. [CrossRef]

11. Krzemień, A.; Sánchez, A.S.; Fernández, P.R.; Zimmermann, K.; González Coto, F. Towards sustainability in underground coal mine closure contexts: A methodology proposal for environmental risk management. J. Clean. Prod. 2016, 139, 1044-1056. [CrossRef]

12. Duda, A.; Valverde, G.F. Environmental and Safety Risks Related to Methane Emissions in Underground Coal Mine Closure Processes. Energies 2020, 13, 6312. [CrossRef]

13. Szwedzicki, T. Program for mine closure. Miner. Resour. Eng. 2001, 10, 347-364. [CrossRef]

14. ISO 31000 Risk Management_Guidelines; International Organization for Standardization: Geneva, Switzerland, 2018.

15. Mining Association of Canada. Whitehorse Mining Initiative. Leadership Council Accord; Natural Resources Canada: Ottawa, ON, Canada, 1994.

16. EU Freshwater Fish Directive Directive 2006/44/E.C. of the European Parliament and of the Council on the Quality of Fresh Waters Needing Protection or Improvement in Order to Support Fish Life. Off. J. L 2006, 264, $20-31$.

17. E.U. Directive on Environmental Quality Standards Directive 2008/105/E.C. of the European Parliament and of the Council of the 16th of December 2008 on Environmental Quality Standards in the Field of Water Policy. Off. J. L 2008, 348, 84-97.

18. Polish Ministery of Environment Regulation of the Minister of Environment of the 18th Of November 2014 on the Conditions to Be Met When Discharging Sewage into Waters or into the Ground and on Substances Particularly Harmful to the Aquatic Environment; Official Journal of the 16th of December 2014, Id. Number1800; Polish Government: Warsaw, Poland, 2014. (In Polish)

19. IEC/ISO 31010 Risk Management-Risk Assessment Techniques; International Electrotechnical Commission/International Organization for Standardization; International Organization for Standardization: Geneva, Switzerland, 2009.

20. González-Quirós, A.; Fernández-Álvarez, J.P. Conceptualization and finite element groundwater flow modeling of a flooded underground mine reservoir in the Asturian Coal Basin. Spain. J. Hydrol. 2019, 578, 124036. [CrossRef]

21. Ordonéz, A.; Andres, C.; Álvarez, R.; Jardón, S. Aprovechamiento de las aguas subterráneas como recurso hídrico y energético. Seguridad y Medio Ambiente 2010, 118, 46-60.

22. Todorov, I.; Harizanov, M.; Stoikov, S. Selecting Drilling Fluids for Mineral Exploration—Diamond Core Drilling and Planning the mud Program for Applications in the Chelopech Cu-Au Deposit (Bulgaria). Górnictwo 2009, 287, $263-271$.

23. Todorov, I. New tendencies in diamond drilling technology with impregnated core bits. Geol. Miner. Resour. 2018, 6-7, 35-40. 